\title{
Bungalows and their Typology in the Colonial Town: Ambala Cantonment
}

Eva Prasher

DCRUST, Murthal

Email: ar.e.prasher@gmail.com

\section{ARTICLE INFORMATION}

Received: September 12, 2016

Revised: October 20, 2016

Accepted: November 2, 2016

Published online: January 02, 2017

Keywords:

Bungalow, British, Evolution, Layout, Building typology

DOI: http://doi.org/10.15415/cs.2017.42008

\begin{abstract}
'Bungalow' has been the most representative element of the built environment of colonialism. It is associated with Europeans; although it developed in India, both in terms of name and form. The evolution of this Anglo-Indian residential typology shows how this indigenous mode of shelter, that was adopted and adapted by the Europeans, fulfilled the physical, social and political requirements of the mercantile and the administrative European officers. Among the urban centers established by the British in India, Ambala Cantonment was an important station due to geographical and political reasons. This Anglicized town that settled in 1843 bears the elements of a typical cantonment and is worth scrutinizing as it possesses all three residential types; the bungalows, havelies and shophouses. The bungalows that evolved a century and a half ago were resultant of cultural and social collaboration of the ideologies of the Europeans and the indigenous. It cannot be denied that the bungalows gradually brought about change in the lifestyle habits of the indigenous and impacted their understanding of health, cleanliness and hygiene. This paper, as part of the study, focuses on the bungalows of Ambala Cantonment with respect to their planning philosophies and elements. The bungalow had developed as a typology by the time this Cantonment was established. Primarily similar, these bungalows differ in terms of layout, largely in the arrangement of their rooms and this study categorizes the bungalows on this criteria.
\end{abstract}

\section{Introduction}

During colonization, the Indian cities underwent a conspicuous transformation in terms of its architecture as well as urban fabric. These changes were due to the advent of modernization, which brought with itself the change in paradigms of urbanization. There are number of factors that contributed in defining the character of urbanization in Indian cities. These factors included the mission to project imperial notions of authority, role of military priorities, import- export trade, need to establish social stability and emergence of new imperial central theme. [6] With housing being an essential requirement, for a new settlement to function as an administrative base, an appropriate housing typology was required to be evolved that would answer the needs of the British officers. These residential buildings were supposed to measure up to the lifestyle of the Europeans backhome, be unique in design to clearly demonstrate the social bias, provide climatic comfort and provide hygienic and clean living environment to the occupants. The answer to all these requirements was the 'bungalow'.

The bungalows evolved from vernacular style of cottage construction in Bengal. This is where the initial layouts and construction went through various stages of modification most of which were derivations from the various types of Bengali huts. [11] The initial forms of the bungalow involved kuchcha construction with thatch roof while the later verses being the pucca construction methodologies and materials. Ambala Cantonment was established in the year 1843. By then British officers had enough experience of constructing bungalows in North India. The bungalows were constructed for Europeans, thus were located in the British occupied area of the Cantonment town. The bungalows of this cantonment have typical elements that make them climatically comfortable, aesthetically appealing and environmentally sustainable. The type of planning was restricted for the British and rightly demonstrated the supremacy and social bias. Juxtaposed to this, were the residential buildings for the natives. The residences for the indigenous were the havelies and the shophouses. The layout and form of the shophouses varies tremendously but the havelies had certain features and layout inspired from the bungalows, although, the two are very different in many aspects.

\section{The Urban Centers}

The urban centers that emerged in India during the Raj may be identified as indigenous, anglicized and model colony 
towns. The indigenous towns have less visible changes in their urban fabric from the native urban form. On the other hand, the anglicized towns are the ones having 'western' add-ons to the native urban form. These additions were although, not superimposed on the existing town, but came up as a suburb and later these developments encircled the old city or the town. [14]Separate colonies were established outside the towns and cities by the British to serve as district headquarters because they felt that the indigenous centers were distasteful, noisy and unhealthy.[13] The model colony towns were new and planned towns. They came up with civil lines or civil station as the main hub of activity, where the officials as well as their residences were located.

There are cities like Lucknow, where advent of the British settlement resulted in the differentiation of the overall urban space as the white and black towns. The white towns were characterized by the presence of military Cantonments with a high concentration of Europeans. The urban layouts of these white towns reflected the health, sanitary and aesthetic concerns of the Europeans, which were different from the indigenous hygiene ethics. Juxtaposed to the white towns, the black towns or the towns for the natives were associated with dense clusters of shops run by native merchants, unplanned forms of streets and housings and neighborhoods that were built around the religious and caste affiliations. This urban power supported the social sustainability besides the claims to 'traditional' influence by the local elites.

\section{The Cantonment Towns and Cities}

The towns and cities created during the British Raj had typical city plans with Cantonment, Civil Lines and residential bungalows as the basic components. Cantonments formed a vital part of the new city plan. The word Cantonment originates from 'canton', meaning to quarter, divide or to cut or separate. Thus a Cantonment was an enclosed area separated from other socio-spatial units and further divided into smaller spatial areas. For security reasons, the Cantonments were situated at strategic locations but close to the major centers of population. Certain cities had the western style central business district with large-scale retail establishments at the city center. These central business districts had low density, in contrast to the indigenous Indian cities where the chowks were a combination of high-density commercial and residential zone. Another core adjacent to this formed the official buildings like courthouse, government offices, post office and railway headquarters. The location of the church formed the vital part of the whole layout while a school and a club were also integrated in the scheme.[14]

The built environment and the spatial organization of the Cantonments demonstrate that the basic principal for the establishment and construction was racial segregation. The structures like barracks were meant for the British troops, lines were for the Indian sepoys and the bungalows for the British officers. There were separate exercise grounds, parade grounds, hospitals, churches, cemeteries, canteens and shopping areas for the Europeans as well as the natives. An additional feature was the regimental bazaar for the sepoys.[13] While the natives continued with the traditional construction methodologies. Later constructions by the elite or the favorite families among the natives show the emergence of a new vocabulary that evolved from the indigenous and was influenced by the European adaptations. The cantonment town gradually had widely dispersed structures to meet the all the basic needs of a garrison. These
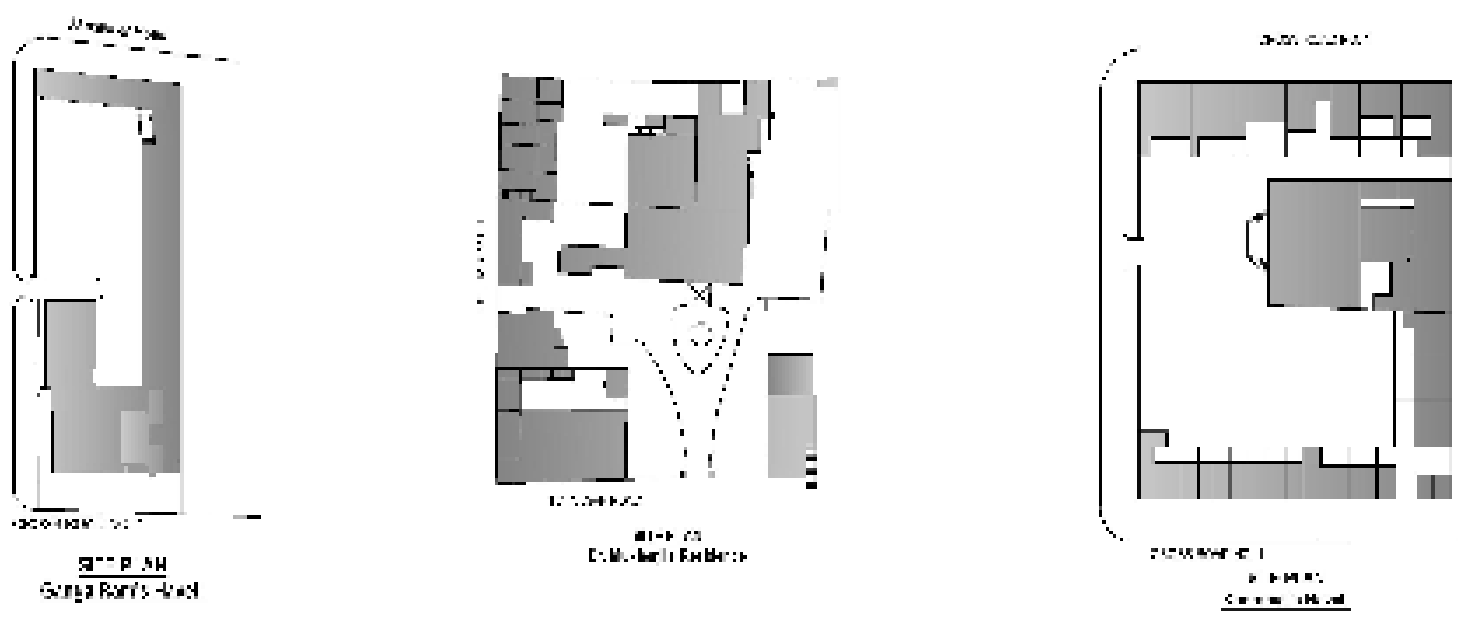

Figure 1. Site Plan of three of the havelies (the hatched being built up area). 
included the shooting ranges, gun-sheds, horse-lines and magazines in addition to workshops and farms.[13]

\section{Planning Philosophies of Ambala Cantonment}

The British established Ambala Cantonment in 1843. In 1849 Ambala became the headquarters of a district and division under the newly formed Punjab Administration. [5] By the year 1868, Ambala was among the six urban centers (others being Lahore, Peshawar, Rawalpindi, Sialkot and Simla) which collectively housed seventy-three percent of the Europeans in the region.[13] It was an important station on the route from Delhi to Lahore and from Delhi to Simla. This 'anglicized' town was established in the southeast suburbs of the existing old city of Ambala which has its history dating back to $14^{\text {th }}$ century. [5] The cantonment was designed with two major grid layouts, one housing all the basic requirements of a garrison and the other as the civic area, which was occupied by thirty-six odd families of different professions as a support system.[10]As the railway station was typically located a short distance away from the core residential area,[13] similar planning is Ambala Cantonment, where the railway station lay in the south-west end of the cantonment, on the Grand Trunk road.

The civic area is called the Sadar Bazaar, which occupied 484.84 acres of land ${ }^{1}$. It possesses twelve streets running from south-east to north-west called the Cross Roads and intersecting theses are eleven streets that run from north-east to south-west. These streets carve out some odd 108 ahatas $^{2}$ and mohallas ${ }^{3}$. These ahatas and mohallas were residential areas of the individual religious or trade community. The central open space within the Ahata was hub of interaction, the activities related to trade or profession and petty social gatherings. On the outer periphery of this grid were the areas like vegetable gardens, open space for religious and public gathering, Dhobi ghat, flour mills, ice factory and structures related to public services like water works and a dump yard. This was in total contrast to what was happening in Ambala city. The urban fabric of this historic town was in alignment with the indigenous growth pattern of most of the towns in the northern India. The organic pattern interweaving the areas different in terms of usage, character and occupancy witnessed the growth of the

\footnotetext{
${ }^{1}$ Data from the map of Ambala Cantonment (1905) reprinted and published under the direction of Brigadier Sir E.O. Wheeler, M.C., Surveyor General of India

${ }^{2}$ Each ahata is a square or rectangular residential area that has an introvert planning and one or more entrance gates. The centre of the ahata is a courtyard, meant for the social interaction and houses lined on all four sides. The outer periphery of the ahata is lined up with shophouses.

${ }^{3} \mathrm{~A}$ mohalla typically comprises of one or more ahatas.
}

city over the ages. The sense of cleanliness and hygiene of Indians was always considered substandard by the British, which is why the 'native areas' were believed to be home for diseases. Physical features or boundaries were used as cordon sanitaire to define the area beyond which the land was forbidden for the British. It was believed that moving in the 'native areas' across these limits would mean carrying the disease causing germs from the 'unhygienic' part of the town to the British occupied area. In Ambala Cantonment, the gurguriyanallah (a drain) was the boundary line to segregate the Native Cavalry Lines in the East and the Sadar Bazaar area in the South. The railway track, in the South West was periphery across which was the Native Infantry Lines. The British families did not go across these hygiene limits nor did the British troops.

Within the Cantonment, the structures that lay in the European occupied area and the area for the indigenous population, clearly demonstrate discrimination as the basic principal during construction. From the overall urban fabric to the individual residential units, the vocabulary of the built forms varies for the two sects of population. Huge plot areas placed in a clear irregular, rectangular grid carved out with wide roads define the European side of the town while across the cordon sanitaire, the urban fabric comprised of dense rectangular grid with streets in hierarchy classifying the each bazaar dominated by a trade community. The streets of Sadar Bazaar are lined up with shophouses on both sides of the markets dedicated to a single profession or trade. These shophouses are typically two to three storey high structures with shops on the ground floor and residence on the upper floor. Thus there was a huge difference in the density in both the areas.

\section{Types of Residences}

The type of buildings in the Sadar Bazaar area included the schools, college, dharamshalas, hotels, shophouses, havelies, hospitals, temples, mosques, gurudwaras, post office, police station, dhobi ghats while the structures on the other side of the cordon sanitaire include the churches, offices, bungalows, barracks, cemetery, clubs, theater, cricket grounds, parks and gardens. Housing being one of the primarily required structures, the discriminate typology of built forms in the cantonment included barracks for the sepoys, bungalows for the British officers, shophouses for the native merchants and havelies for the elite natives. Shophouses being the typology for the merchants, the Sadar Bazaar area has streets lined up with shophouses on both sides. The havelies were luxurious houses on lavish plot sizes within the Sadar Bazaar area. These havelies were limited in number and belonged to the favorites of the British officers. 

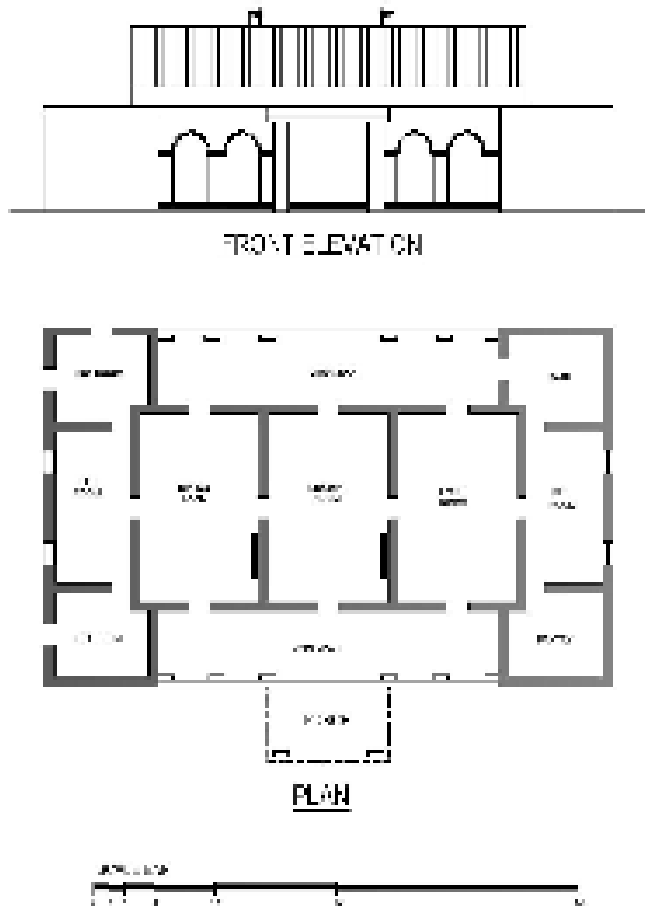

Figure 2. Layout of bungalow with three adjoining living rooms.

\subsection{The Havelies}

The havelies in Ambala Cantonment were the residential buildings that typically belonged to the favorites of the British officers. These did not flourish as a type in this township as they were limited in number, and bear elements of both the kothi and the haveli. The layouts of these havelies also reflect the interaction of the elite with the British officers and how they influenced their understanding of health and hygiene. Unlike the houses of the commoners, the havelies had bathrooms attached towards the external corner of the structure. Standing outstandingly on a large plot that spanned from one chowk to another, the havelies were huge structures. The houses of the servants lay within the boundary of the plot. Garden was not a common feature in all the havelies.

Although very few in number, these havelies stand out in the urban fabric of Sadar Bazaar area. This is because unlike the other residential buildings for the natives, the shophouses, the havelies occupied one complete sector that was carved out from intersection of two adjacent streets with two adjoining crossroads.
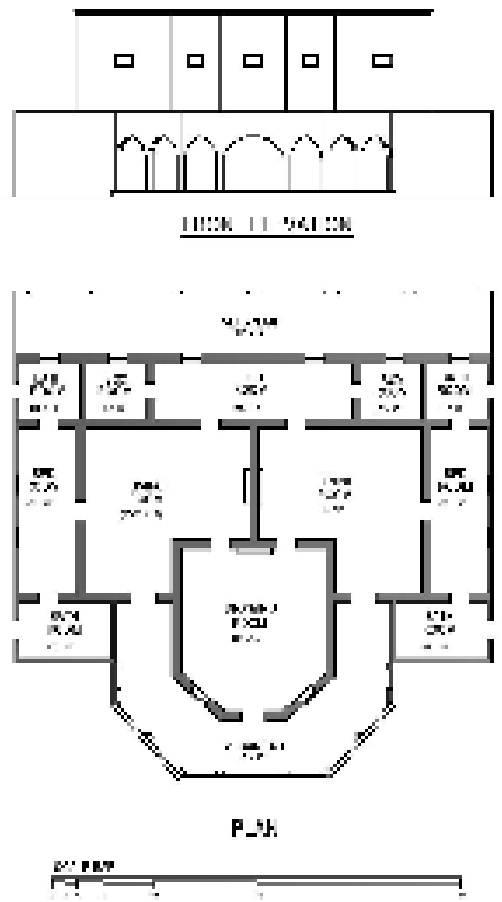

Figure 3. Circular front with verandah all around.

These havelies were single to two storey high structures. The exposed brickwork on exterior walls possesses intricate patterns especially on the parapet with the use of bricks in different size and at places, shapes. One of the haveli was popularly known as the Marble house as it was externally cladded with white marble.

\subsection{The Shophouses}

Besides bungalows, shophouses are architectural residential typology that evolved during the Colonial era. As the name suggests, the shophouses were designed for the merchants to set up their business at the ground floor while reserve the upper floors for residential purposes. The typical shophouses of Ambala Cantonment are two to three storied structures with shops at the ground floor and residences at the upper floors. The shophouses have highly ornamented facades with protruded balconies running on all external walls. These balconies, supported over heavy timber logs and girders bear intricate railing patterns made out of thin iron rods. The sloping roof of GI sheet is supported over timber posts and pillars. Thin iron sheet pelmets, 
with intricate cutout pattern lace the GI sheet edges. In certain shophouses, the balconies are covered for functional purposes with timber louvered, openable shutters. These, at times, function the same as jharokhas. Shophouses have a central courtyard with rooms on all sides. These opento-sky central courtyards keep the interiors cool and are responsible for supply of fresh air and natural light to the interior spaces. The overall layout of the shophouse is a well-calculated arrangement of rooms, which are small or optimum in size. Occasionally, one can find a room that is deep and narrow.

With multiple shops at the ground floor and residential area on the upper stories, the floors are connected through narrow and dark staircase. The tread was kept high to cut down the space occupied by the staircase. The toilets were on the terraces with manual cleaning system, thus the staircases had a direct access to the terrace without entering the living areas of the house. The shophouses are aesthetic and functional units that exhibit the most splendid artwork in its architectural elements but no way were the spaces lavish or influenced by the European lifestyle.

\subsection{The Bungalows}

The bungalows are a celebrated architectural style that had evolved in Bengal in 1770s.[11] The bungalows evolved out of the need of the British to design themselves structures that were climatically comfortable and at the same time reflected their power and supremacy over the Indians. The bungalow, as a style, emerged from Bengal where it was the resultant of understanding of the Indian vernacular techniques of countering the harsh climate and symbolizing the superiority in terms of social status; fit into the new understanding of modern architectural by the British. Consequently, the bungalows define the traditional use of elements and materials with a modernistic approach. Bungalows possess certain exclusive characteristic features, which clearly indicate their luxurious life. Also, there are certain features that reflect the nostalgia and modernity that the British carried with them. These features and architectural elements were unknown to the local architectural perception; thus, the resultant created was the indigenous version of the foreign.

\subsubsection{Origin and Initial Forms of Bungalow}

Deriving their name 'Bungalow' from the Bengali term 'Bangala' meaning house, the bungalows of Ambala Cantonment speak of incomparable residential structures that were introduced in the region with the advent of the British. The bungalows, as a product, were an answer to the various requirements of the British officers.[3]
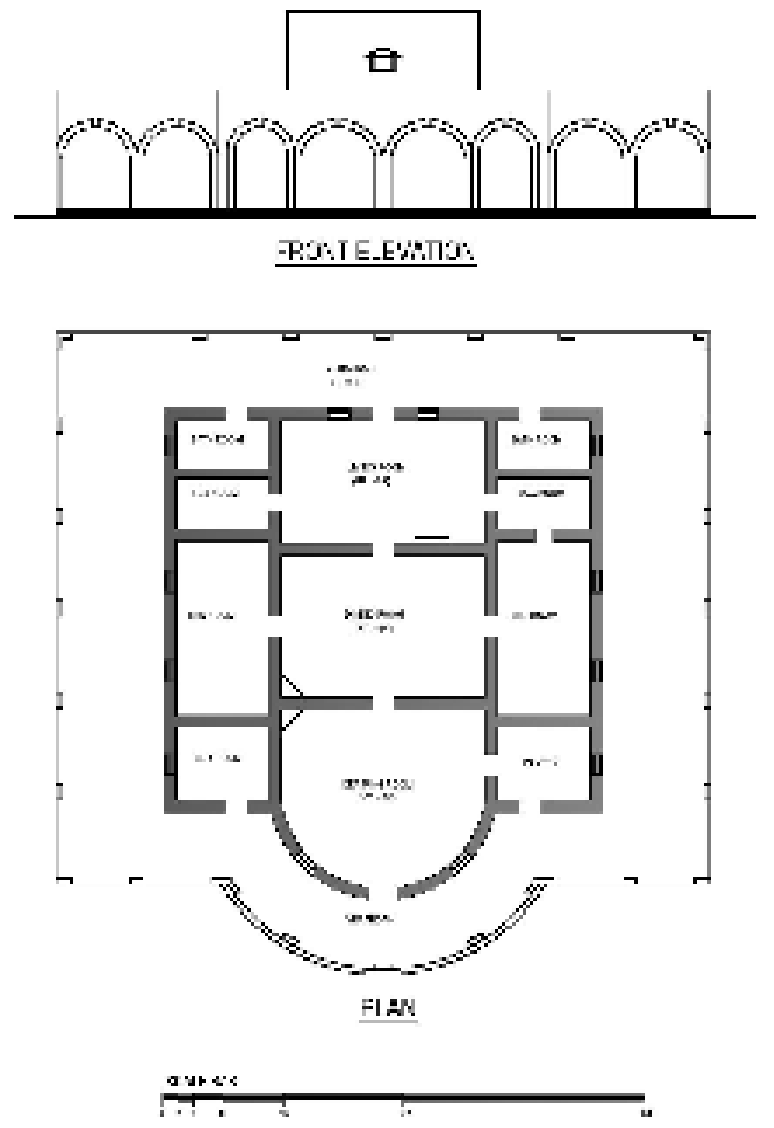

Figure 4. Circular front with verandah all around.

Although, the real Anglo-Indian 'banggolo' was a later modification of what was originally used by the British as a housing type. The initial form of cottages used was derived from 'Chauyari', which literally means 'four sides'. The plan was either a square or rectangular and accordingly had truncated triangular sloping thatch roof. There are great improvements that were made to this style of cottage like the addition of a gallery that surrounds the entire cottage to exclude the heat. This concept of gallery being introduced has been a point of debate as 'gallery' was already a part of the architecture being used in Bengal.[11]Its layout has the central square of the cottage divided into one or more compartments, depending upon the circumstances and needs of the individual. The thatched roof extended on all sides, supported with wooden pillars or bamboo on extreme edges that resulted into a verandah. This verandah is enclosed with mat and at times a brick wall in further improvisations. Putting partition walls along the corners resulted into small rooms, that we later see being used as box rooms and bathrooms.[11] 


\subsubsection{Typical Bungalows of Ambala Cantonment}

The bungalows of Ambala Cantonment were constructed in and after the year 1843 and by this time; the bungalows had flourished as a typology. Thus, these bungalows bear the basic elements of what had developed as a style for this particular part of the country. Typically, the bungalows are placed in the middle of the plot with gardens on all sides. This feature grants the bungalow its gigantism and authoritative ambience. Besides this, the gardens or the open green spaces on all sides help tackle the harsh summers in the composite climate of Ambala. Unlike the indigenous houses, the shophouses, the bungalows did not have the central courtyard to bring down the temperature of the rooms and keep the air circulating. It was rather the green space around that brought in the fresh and cool air to the interior spaces.

The bungalows in Ambala Cantonment are also placed in the middle of huge plots of size varying from 1.2 acre to 2.6 acre. The residences of the Europeans had the entire essentials, except the well, at the rear of the house, including the outhouses for the people providing services.[13] The rectangular plots have one or two entrance gates. The gateposts are bulky hexagonal or octagonal five to six feet high brick structures. The caricature of gateposts of each bungalow was largely the same, but varied in detailing. The bungalows are typically a single story structure with a plinth height of one, two or three feet. The initial materials of construction were the kuchcha materials including the sundried bricks, thatch and bamboo. Later, the drawbacks were realized and the construction started to be pucca in nature[11]. The building materials now used were the burnt bricks laid in lime and surkhi mortar. The interior of the 13.5 to 21 inches thick wall surfaces were plastered with lime and surkhi but the external facades were largely left with exposed brick work.

The locals that constructed these bungalows for the British were mainly Hindus and Muslims [5]. Accordingly, the kitchen was placed in the premises. Although the Indian lifestyle suggests the kitchen attached to the house, but the British required keeping the native helpers away from the living space. This was politically and hygienically, better for the Europeans. Thus, the kitchen was not directly attached to the house. The Muslims constructed completely detached kitchens on the site, whereas the Hindus had kitchens attached to the main bungalow, but with a separate entrance for access, or very close to the bungalow. There is mostly a door in the dining room that led in the open towards the kitchen, from where the food was served.

The Muslims of the region had a custom of burying their ancestor priest $^{4}$ in the private premises. Thus, the

${ }^{4}$ Interviews suggested that each Muslim family of the region considered one of their great grandfathers as a priest and the entire family used to worship him. The grave of this holy priest existed in the rear bungalow garden. bungalows built by the Muslim families possess a grave in the rear garden. Similarly, a well also existed in most of the bungalow premises. The elite members of the then society were granted the privilege of a horse pulled buggy. So, on the site, existed a garage for parking of this special horse cart. Practicing a modern lifestyle, the British families had the liberty of appointing a minimum of six and maximum of twelve daily help servants. These servants stayed in the linearly placed single room outhouses in the compound.

Certain bungalows were accessed through a porch that protruded prominently from the main façade. This conventionally ten feet high portico was supposed to facilitate the embarking and disembarking of the British families into their buggies or the horse carts. Typically the porch had a roof of brick tiles supported by timber joists and further with heavy iron girders. This heavy roof was supported over thick brick walls with arched punctures. Later, on the introduction of electric supply to the bungalows, the electric cables were derived into the bungalow with the help of hooks suspended in the porch ceiling. On analysis, the span and depth of the porch was largely found out to be in the ratio 1:1.6.

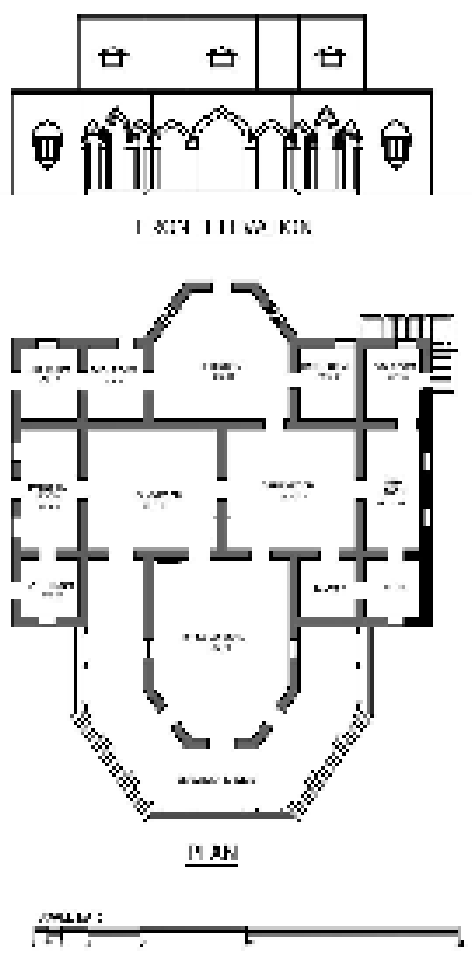

Figure 5. Bungalow with octagonal front and rear façade 

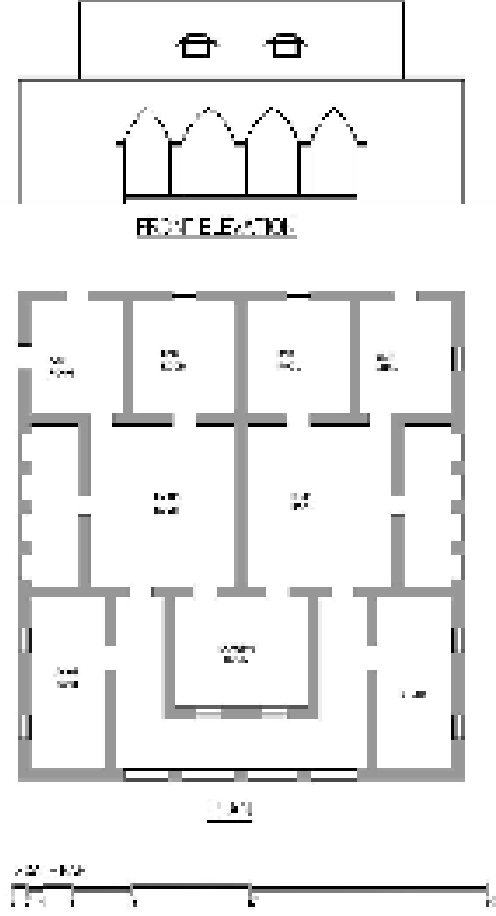

Figure 6. Layout of a typical type 4 bungalow

The porch of the bungalows conventionally leads to a verandah. These are shady arcaded corridors that surround the bungalow from one or all sides. The depth of the verandah varies from eight feet to ten feet. These verandahs over looked at the surrounding gardens and served as the leisure sit-outs for the occupants as they are cool during the harsh summers. The central rooms of the bungalows are the living area, the drawing room and the dining room. One or each room has a direct access from the entrance verandah. These spacious rooms were apt to exhibit the luxurious and nostalgic lifestyle of the British. These rooms have ceilings as high as twenty-four feet. The surrounding rooms have a typical height of ten feet. The additional height is used to accommodate ventilators on all sides. This allowed additional light and facilitated ventilation of hot air so as to keep the rooms cool during summers. These central rooms have fire places mostly located on the common wall between two living rooms. The chimneys of these fireplaces open on the terrace. The size of these rooms varies from 350 square feet to 665 square feet. The thick brick walls laid in lime and surkhi mortar make the rooms exceptionally comfortable against the extreme heat or cold outside. The rooms with ceiling height of ten feet were used as bedrooms, study and dressing rooms. Typically the corners of the bungalow are the box rooms and bathrooms. One door of the bathroom opens out to the open. This made it convenient to get the water filled without letting the bhishti enter the living areas.

\subsubsection{The Various Typologies}

It is interesting to note that usage of the rooms was by and large the same in each bungalow. The three rooms with high ceiling being the drawing room, the dining room and the living room, decided the basic form of the entire structure. The bedrooms or the retiring spaces were displaced around these core spaces. The bedrooms were generally deep but optimum in width. These rooms were cozy spaces with not much additional furniture. The corners of the building were the box rooms and the bathrooms. The additional door in the bathroom that opened to the open spaces was meant for the bhishti to refill the water for bathing purposes. The remaining rooms were in some cases used as dressing-cumstorage rooms and/or as study. The verandah was a very useful place for evening sit-outs.

The placement of the three living rooms largely defines the overall profile of the bungalow. The layout of bungalows studied in Ambala Cantonment can categorically be classified into five types. ${ }^{5}$ Irrespective of layout arrangement that the bungalows followed, each bungalow had well designed natural ventilation. The ventilators on peripheral walls of the rooms with high ceiling allowed the hot air to escape out while the cooler air would circulate within the bungalow through the peripheral rooms. This technology of keeping the interiors cool was inspired from the indigenous methods. On basis of the layout, the five categories of the bungalows are:

Type 1

In this type, generally three and sometimes four rooms are placed adjoining each other in a linear fashion (Figure 3). There are rooms on the two sides of this arrangement used as bed rooms, study and dressing. An indigenous element, the arched verandah, acts as the aesthetic element on the front and the rear facade. The height of the central rooms is 24 feet and that of the other private rooms on the periphery is 10 feet.

\section{Type 2}

In this type, the layout has generally three rooms with height of 24 feet surrounded by 10 feet high areas. In this case, the front facade has round or octagonal profile. There are further two sub- categories that can be found in this layout; one with a verandah only in the front and the rear (Figure 4) and the other with a verandah moving all around the structure (Figure 5). These bungalows do not have a front porch.

${ }^{5}$ This classification is based on the survey and documentation done by the author. The layout plans are from the documentation done by the authors 

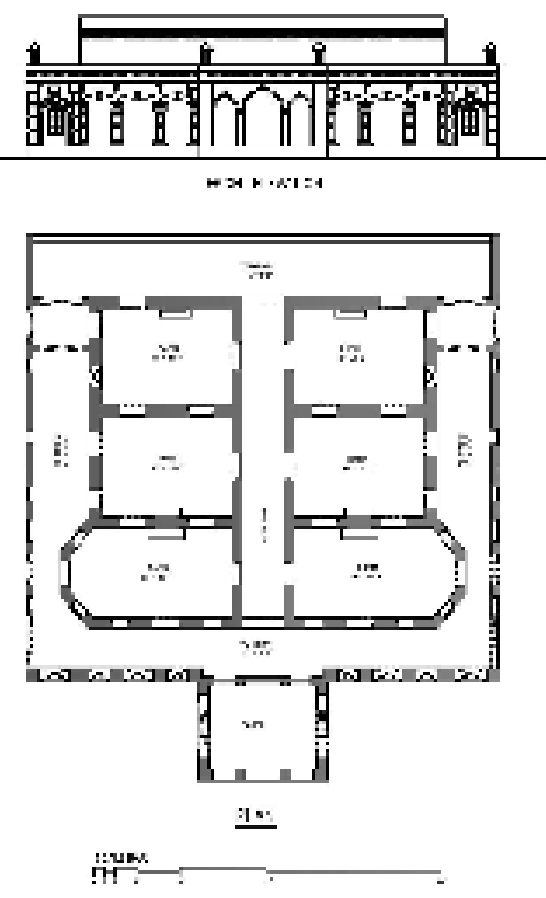

Figure 7. Layout of a bungalow with central corridors and symmetrical rooms on both sides.

Type 3

This type is a variant of type 2 . Here, other than the front facade being in circular or octagonal in shape, the rear part of the bungalow also bears the similar shape (Figure 6). In some cases, the rear circular or octagonal shape could be a verandah, while in others it could be an enclosed room.

\section{Type 4}

This type of bungalows has three and at times four main rooms. In the given illustration (Figure 7), there are three rooms with a height of 24 feet. Here, there is no front porch and but a verandah in the front. In addition to this, there are verandahs that envelope the building on two sides. The rear and the two corners in the front are 10 feet in height.

\section{Type 5}

Type five is the special bungalow type that was not very common. This unique plan was used in the Magistrate's Courts and a bungalow on the Mall Road. In case of the Magistrate's Court, the external corners of the building had octagonal room for staircases that were made of timber. The other features were similar to the other bungalows. This layout has a central corridor running through the middle of the bungalow and there are symmetrical rooms placed on both sides of this corridor (Figure 8). Herein, all the rooms and central corridor has high ceiling and the verandah running around has a ceiling height of ten feet.

\section{Other Bungalows}

Although, majority of bungalows in Ambala Cantonment fall under the above-mentioned categories, there are certain more bungalows that have unique layout. These buildings were meant for a particular purpose; for instance, the bungalow illustrated in Figure 9. This bungalow is under private ownership. The layout of this bungalow is altogether different from the above-mentioned categories. It is a T-shaped plan with five rooms with high ceiling and lavish dimensions indicating the purpose of social interaction space. There are only three rooms and a toilet with moderate ceiling height and optimum dimensions. The facades largely possess the native and vernacular architectural elements. They demonstrate the extraordinary skilled workmanship in terms of brickwork. The use of various sizes and shapes of bricks creates some very interesting patterns on the façade. The parapet walls generally have a number of different patterns of brick jalli. The bungalows bear variation in terms of types of arches. This grants them uniqueness and an unparalleled aesthetic appeal.

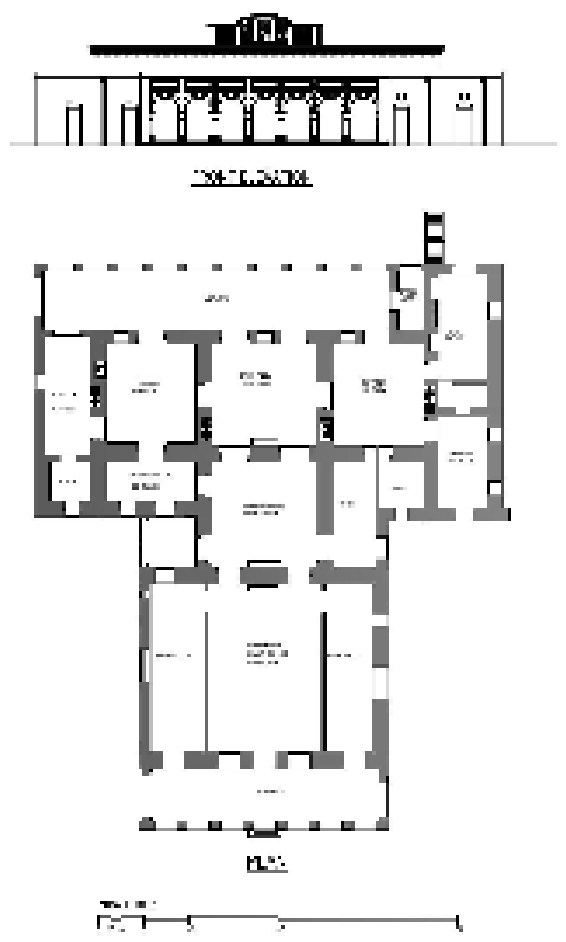

Figure 8. A unique layout of a bungalow with T-shaped plan. 


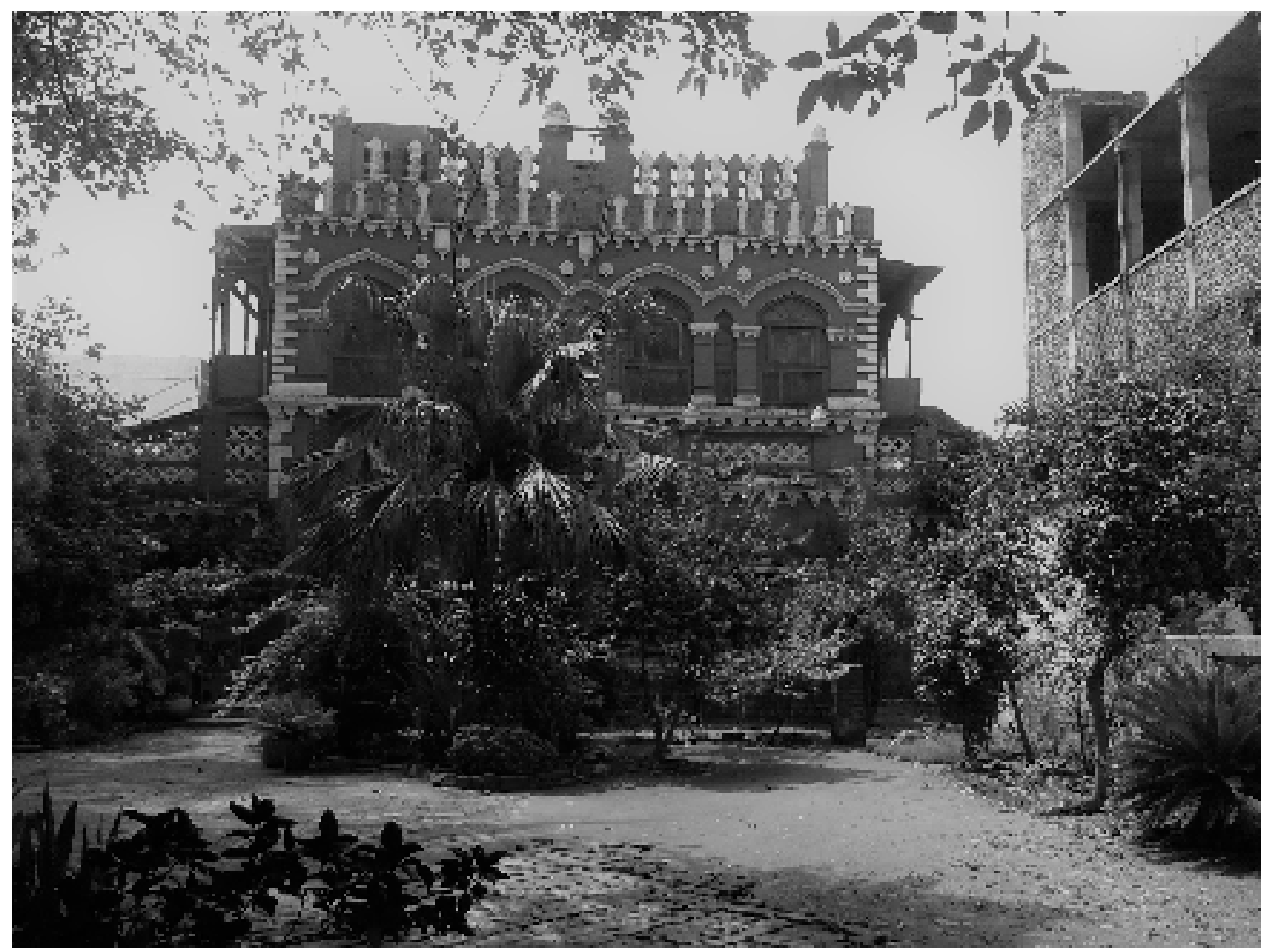

Figure 9. Highly decorative front façade of Dr Mukherjee's Haveli with patters in brickwork, painted in red and white.

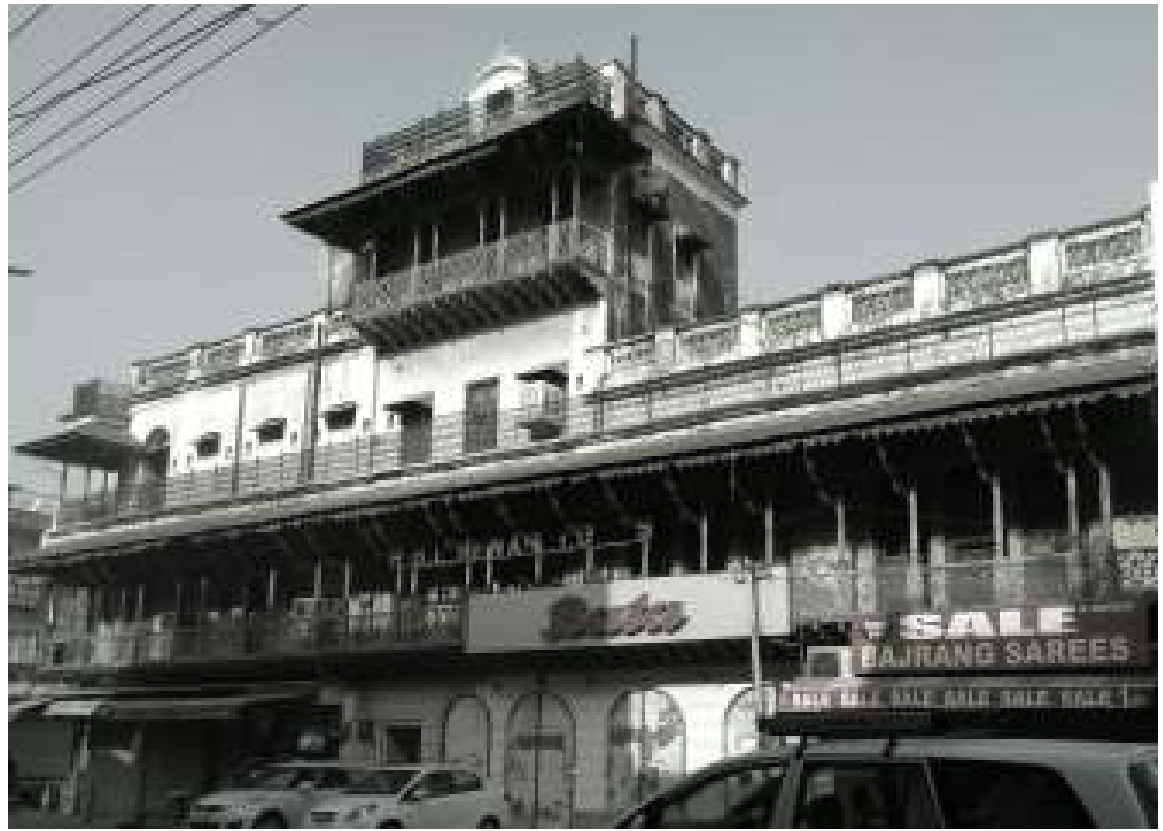

Figure 10. View of Rai Bahadur Lala Banarasi Das's Haveli that extends from one chowk to another. Shops carved out as part of later intervention. 


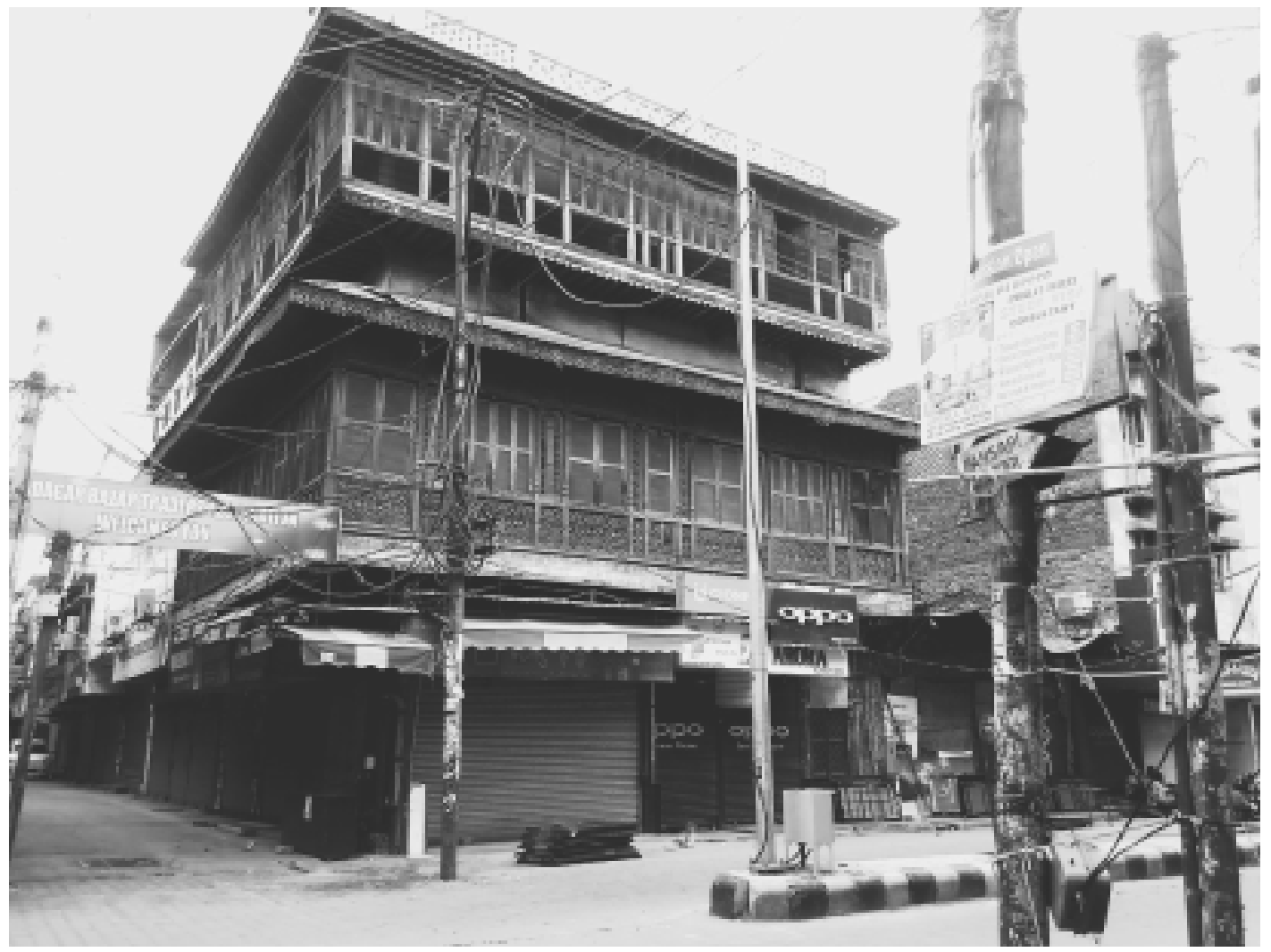

Figure 11. A typical Shophouse in Saudagar Bazaar, Ambala Cantonment

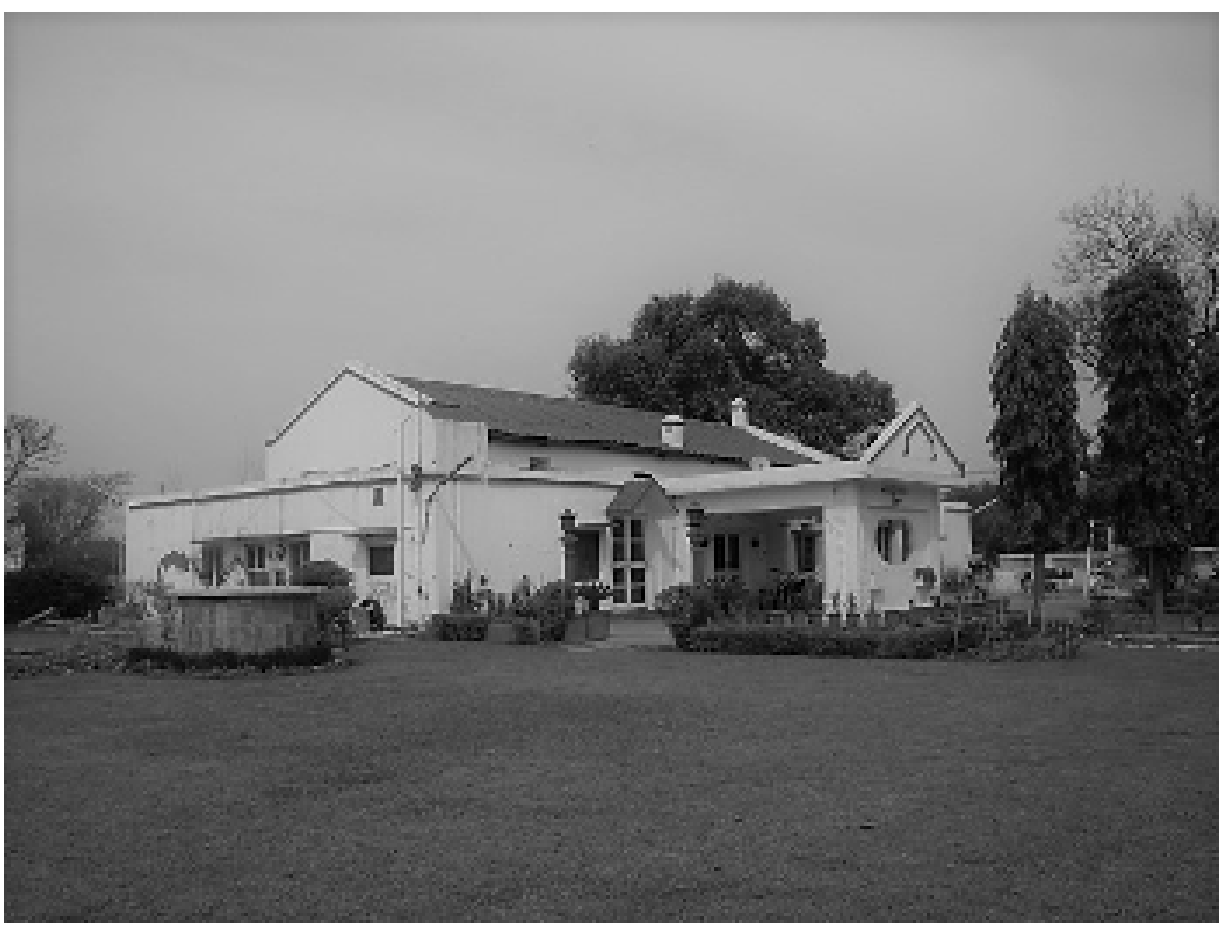

Figure 12. A Typical Bungalow in Ambala Cantonment area, standing in the middle of a huge plot. 


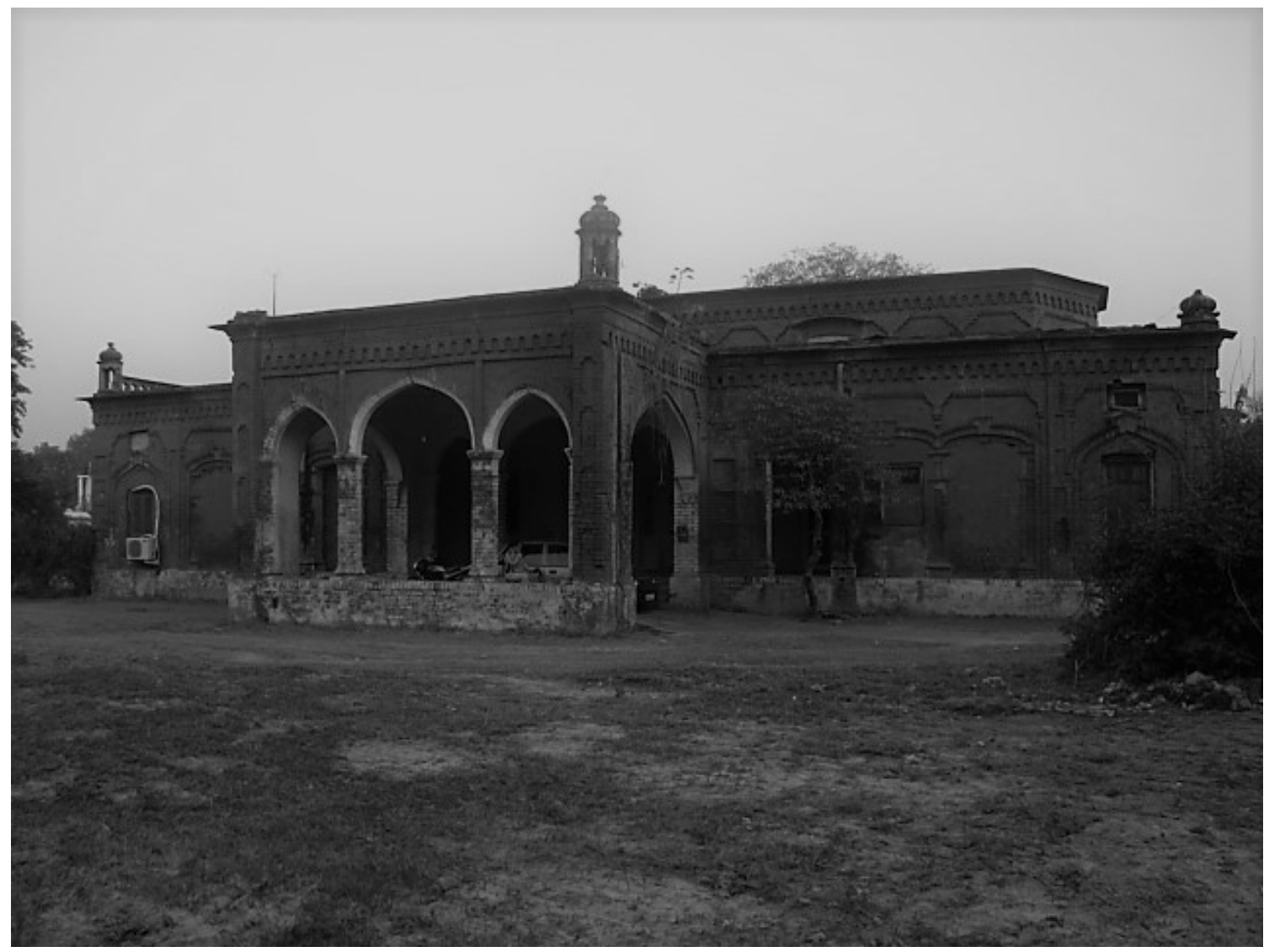

Figure 13. Another Bungalow in Ambala with arched porch and intricate patterns on the facade.

\section{Conclusion}

In Indian context, the advent of bungalows brought in westernization of domestic architecture. People gradually developed transformations in their lives that were not only physical but also behavioral. It would be incorrect to deny the existence of detached or freestanding dwelling units outside the core of the town or the traditional town before the British created Bungalows, but these were for the nawabs and the wealthy families. Also, new housing typologies like kothies developed with the amalgamation of the elements of bungalow and haveli. The understanding of health, cleanliness and hygiene gradually evolved as a mandatory and basic concern, whereas living in traditional houses, eating with fingers while sitting cross-legged on the floor and other lifestyle habits gradually ceased to be part of the routine. Considering the area under study, the issues involved are little complex and need to be approached enduringly because they include policy and practice. The present policies ensure the preservation of the form and structure of the bungalow as well as the overall urban environment in which they exist. But these policies lack a long-term approach. Consequentially, future of these bungalows lies at mercy of the concerned authority. But because of the tremendous change in lifestyle in past 170 years, the bungalows do not suffice the needs in their authentic form. Bungalow owners modify interior of the bungalows without altering external form and structure. Bungalows are supreme illustration of sustainability. The agony is, we are unable to implement these key elements in modern day dwelling units. We need to cherish our past to enable next generations to look up to as a perfect example of livable and comfortable dwelling unit.

\section{References}

[1] CSE. (2014). Do Chala: Bangla Ghar and Vernacular Architecture. Retrieved from http://cdn.cseindia.org/ userfiles/Do\%20Chala\%20and\%20Vernacular\%20 Architecture.pdf

[2] Desai, M., Desai, M. (2011). The Colonial Bungalow in India. Indian Institute of Asian Studies 57. pp. 26-27

[3] Desai, M., Desai, M. (2012). Bungalow in Twentieth Century India: The Cultural Expression of Changing Ways of Life and Aspirations in the Domestic Architecture 
of Colonial and Post-Colonial Society. London; Routledge

[4] Grewal R. (2009). Colonialism and Urbanization in India: The Punjab Region. New Delhi: Manohar Publishers \& Distributors

[5] Imperial Gazetteer of India. (1909). The Indian Empire Volume 1 New Edition. Clarendon PressRetrieved from https://archive.org/details/ imperialgazettee $030583 \mathrm{mbp} /$ page/n5

[6] Haynes, D. E., and Rao, N. (2013). Beyond the Colonial City : Re-Evaluating the Urban History of India , ca . 1920 - 1970. South Asia: Journal of South Asian Studies, 36(3). pp. 317-335 doi: $10.1080 / 00856401.2013 .814617$

[7] Jindal, A. (2010). Revitalization of Built Heritage of Sadar Bazaar, Ambala Cantonment with special focus on Shophouses. Unpublished Thesis

[8] Joshi A. (2008). Town Planning Regeneration of Cities. New Delhi: New India Publishing.

[9] Kagal C. (1986). Cantonments and Bungalows. Vistara - The Architecture of India, Catalogue of the Exhibition, The Festival of India. pp. 100-101

[10] King, A. D. (1982). Bungalow 1600-1980: A Study of Cultural Social, Political and Economic Factors in the Production of a Global House Type. Unpublished Thesis at School of Social Sciences. Uxbridge: Brunel University

[11] Prasher, E. (2010). Development of Bungalow Zone of Ambala Cantonment. Unpublished Thesis Books

[12] Sengupta, T. (2011) Between the Garden and the Bazaar: The Visions, Spaces and Structures of Colonial Towns in Nineteenth-Century Provincial Bengal. Visual Culture in Britain 12(3). pp. 333-348, doi: 10.1080/14714787.2011.613732

[13] Sengupta, T. (2013). Living in the Periphery : Provinciality and Domestic Space in Colonial Bengal. The Journal of Architecture18(6). doi: $10.1080 / 13602365.20$

[14] Talbot, I. A. (2007). The Punjab under Colonialism : Order and Transformation in British India. Journal of Punjab Studies 14 (1) Retrieved from http://www. global.ucsb.edu/punjab/sites/secure.lsit.ucsb.edu.gisp. d7_sp/files/sitefiles/journals/volume14/no1/14.1_ Talbot.pdf

\section{Glossary}

Ahata

Bazaar

Bhishti

Brick jalli

Buggies

Dhobi ghat

Gurudwara

Haveli

Jharokha

Kothi

Kuchcha

construction

Mohalla

Pucca

construction

Surkhi

Verandah
A square or rectangular open community space with two or more entrance gates and houses on all four edges

A traditional market space

A man generally using a leather bag to fetch potable water

A perforated brick wall; the combination of brick and void resulting into interesting patterns

Single horse carts that were employed to fetch the elite and the government officials

A place where a traditional caste of washermen wash clothes

Place of worship for the Sikhs

Mansion; lavish house of the elite

Ornamental enclosed overhanging small balcony; typical feature from architecture of Rajasthan

A house typology; typically a trader's house

Construction carried out with low strength construction material

Neighborhood

Permanent construction carried out with high strength construction material

Brick dust; a traditional construction material

Covered platform that runs along the front of a house 